\title{
Gall-inducing insects of deciduous and semideciduous forests in Rio Grande do Sul State, Brazil
}

\author{
Ana Paula M. Goetz' (1D https://orcid.org/0000-0002-9531-6504 \\ Fernando A. Luz' (iD https://orcid.org/0000-0002-1176-698X \\ Tiago S. P.Toma ${ }^{2,3}$ (D) https://orcid.org/0000-0002-1 144-9597 \\ Milton de S. Mendonça Jr' ${ }^{1}$ iD https://orcid.org/0000-0001-5272-5124
}

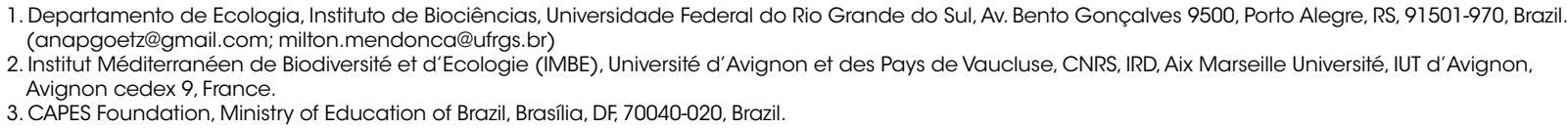

Received 25 January 2018

Accepted 12 April 2018

Published 11 June 2018

DOI 10.1590/1678-4766e2018015

\begin{abstract}
Galls are specific changes induced by insects on plant organs mainly through increases in plant cell number and/or size. Gall diversity is easy to recognize in the field because gallers are mostly species-specific, and thus each gall morphotype can be a proxy for a galling species. Insect galls are virtually unknown in Seasonal Deciduous and Semi-Deciduous forests of southern Brazil. Here, galls and host plants were surveyed between 2015 and 2017 in four forest fragments of Rio Grande do Sul State in these two vegetation types, in secondary-growth and areas under restoration. We recorded 89 gall morphotypes, with gallers belonging to Lepidoptera and Diptera, with the latter represented mainly by Cecidomyiidae. Galls were associated to 46 plant species in 27 families. Asteraceae, Piperaceae, Fabaceae, Myrtaceae and Lauraceae were the richest families in terms of galls, whilst Piper aduncum and Mikania glomerata were superhosts. Most galls occurred in leaves and shoots. The most common shapes were fusiform, globoid and lenticular. Forty-eight gall morphotype records are new for both Rio Grande do Sul and Brazil, an expressive number considering only two seasonal forest types sampled and few sampling points, showing how important surveys still are for these little know fauna both in taxonomic and ecological terms.
\end{abstract}

KEYWORDS. Insect-plant interaction, host plant, morphotype, gall richness.

RESUMO. Insetos indutores de galhas das florestas decidual e semidecidual no Estado do Rio Grande do Sul, Brasil. Galhas são alterações específicas induzidas por insetos sobre órgãos das plantas principalmente através de aumento no número e/ou tamanho das células vegetais. A diversidade de galhas é reconhecível em campo porque os galhadores são na sua vasta maioria espécie-específicos e assim cada morfotipo de galha serve como proxy para uma espécie de galhador. Insetos galhadores são virtualmente desconhecidos nas florestas estacionais deciduais e semideciduais do sul do Brasil. Galhas e plantas hospedeiras foram inventariadas entre 2015 e 2017 em quarto fragmentos florestais do Estado do Rio Grande do Sul nestas duas formações vegetacionais, em áreas com sucessão secundária e sob restauração. Foram encontrados 89 morfotipos de galhas, com galhadores pertencentes a Lepidoptera e Diptera, com os últimos representados principalmente por Cecidomyiidae. As galhas estiveram associadas a 46 espécies de plantas em 27 famílias. Asteraceae, Piperaceae, Fabaceae, Myrtaceae e Lauraceae foram as famílias mais ricas em termos de galhas, sendo Piper aduncum e Mikania glomerata considerados super-hospedeiras. A maioria das galhas ocorreu em folhas e ramos. As formas mais comuns foram fusiforme, globoide e lenticular. Dos morfotipos de galhas registrados, 48 são novos para o Rio Grande do Sul e o Brasil, um número expressivo considerando que somente dois tipos de florestas foram amostradas em um número restrito de pontos amostrais, demonstrando a importância de levantamentos para esta fauna quase desconhecida tanto em termos taxonômicos quanto ecológicos.

PALAVRAS-CHAVE. Interação inseto-planta, planta-hospedeira, morfotipo, riqueza de galhas.

Insect-induced galls are anomalous growth on plant organs originating from increases in plant cell number (hyperplasia) and/or size (hypertrophy) (MANI, 1964). Galling insect species can even be separated and identified based on gall morphology along with host plant organ and species (PRICE et al., 1998). Each galling insect species is responsible for inducing a unique structure, a gall with distinct anatomy and physiology compared to other such species (SHORTHOUSE et al., 2005). Most gallers are species-specific relative to the plant host, with the latter usually belonging to specific plant clades as well, with clear evolutionary associations (MENDONÇA, 2007). New surveys of these gall-based plant-herbivore trophic networks on unexplored sites and vegetation types can work as repeated tests for these ecological and phylogenetic patterns, with regional preferences either confirmed or revised by new knowledge.

Since the end of the 1980s decade, studies on galling insects increased considerably in Brazil, mainly related to natural history and distribution (FERNANDES et al., 2014). Nowadays, work is being carried out in all different regions 
of this country: North (e.g. Almada \& Fernandes, 2011), Northeast (e.g. NogueIra et al., 2016), Central-West (e.g. AraúJo et al, . 2015) and Southeast (e.g. Maia \& CARvalhoFERNANDES, 2016). In Southern Brazil, studies on galling insect diversity are still scarce, however there are recent records for Paraná (CARvalho et al., 2015; SANTOS \& Ribeiro, 2015) and Rio Grande do Sul States (e.g. DALbem \& MendonçA, 2006, MendonÇA, 2007, 2011; MendonÇA et al.; 2010, TOMA \& MendonÇA, 2013). MendonÇA et al. (2014) listed insect galls known from the two biomes occurring in Rio Grande do Sul (RS), Atlantic forest and Pampas. Surveys covered different vegetation types, mostly subtropical gallery forests and subtropical moist forests, without being able to represent Seasonal forests, a rather common vegetation type in the region.

This study aims to increase the present knowledge on galling insects and their host plants by surveying Deciduous and Semideciduous Seasonal forests in Rio Grande do Sul State and comparing with already established ecological and evolutionary patterns on gall occurrence.

\section{MATERIAL AND METHODS}

This study was carried out in forest fragments of Semideciduous Seasonal (SS) and Deciduous Seasonal (DS) forest formation types, in two localities of Rio Grande do Sul State, Brazil. SS samples took place in Canela municipality, in an area belonging to the State Electric Company (Companhia Estadual de Energia Elétrica, CEEE-RS). Samples in DS occurred in Santa Tereza municipality, in private property areas with authorisation granted for scientific research.

The SS sites face a $C f b$ climate (Köppen classification) with average temperatures for the hottest month at $22^{\circ} \mathrm{C}$ and for the coldest month from $-3^{\circ} \mathrm{C}$ and $18^{\circ} \mathrm{C}$ (Moreno, 1961). This type of forest formation is characteristic of regions with temperature climatic seasonality and has a percentage of deciduous trees between 25 and 50\%, evident in the winter (IBGE, 2012). The DS sites are under a $C f a$ climate with average temperatures for the hottest month above $22^{\circ} \mathrm{C}$ and for the coldest month from $-3^{\circ} \mathrm{C}$ and $18^{\circ} \mathrm{C}$ (Moreno, 1961). As with the SS forests, DS occurs in seasonal environments, having however at least $50 \%$ of trees losing leaves in the cold season (ESPÍRITO-SANTO et al., 2006).

Eight seasonal samples were done during 2015 and 2017 (one yearly sample for autumn and winter and three yearly samples for summer and spring) in four forest fragments (two for each vegetation type) in two distinct successional stages. For the SS forests in Canela, two fragments had advanced secondary growth $\left(29^{\circ} 22^{\prime} 58.1^{\prime} \mathrm{S}\right.$, $50^{\circ} 44^{\prime} 08.1$ "W and 29 $22^{\circ} 50.4$ "S, 50 44'11.9"W) and two others had 10 years since restoration actions were undertaken (29 22' 50.2'S, 5044'03.2' $\mathrm{W}$ and $29^{\circ} 22^{\prime}$ '44.1' $\mathrm{S}$, $\left.50^{\circ} 43^{\prime} 49.8^{\prime} \mathrm{W}\right)$. For the DS forests in Santa Tereza, there were also fragments being the first two at an advanced secondary

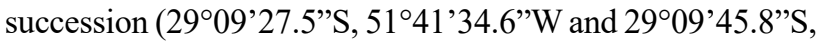
$\left.51^{\circ} 42^{\prime} 33.2^{\prime \prime} \mathrm{W}\right)$, as well as two areas with eight years since restoration took place $\left(29^{\circ} 09^{\prime} 44.8^{\prime}\right.$ 'S, $51^{\circ} 42^{\prime} 32.8^{\prime \prime} \mathrm{W}$ and $\left.29^{\circ} 09^{\prime} 47.8^{\prime \prime} \mathrm{S}, 5^{\circ} 42^{\prime} 40.5^{\prime \prime} \mathrm{W}\right)$. Each fragment was explored by two persons during $60 \mathrm{~min}$ in search for galls in all plant species. Overall there were $64 \mathrm{~h}$ of sampling in each locality.

All galls were collected and took to the lab, where they were separated in morphotypes according to external morphology in combination with galled organ and host plant species. Galls were photographed, dissected under stereoscopic microscope to obtain immature galling inducers and characterize and describe galls (shape, colour and number of chambers) according to IsAIAs et al. (2013).

Part of the sampled galls was kept in sealed plastic bags to obtain adult galling insects. These were preserved in $70 \%$ ethanol and identified to the lower taxonomic level possible. However, some gall morphotypes were found empty, which made inducer identification impossible, although there is no doubt these galls were insect-induced. Host plant shoots, reproductive when possible, were identified with the help of taxonomic literature and/or botanical specialists. Biological material is deposited in the scientific collection of the Laboratório de Ecologia de Interações, UFRGS. Host plant taxa were organised according to Angiosperm Phylogeny Group IV classification (APG, 2016).

\section{RESULTS}

Overall 89 gall morphotypes were found, with most insect inducer species being Diptera, and Cecidomyiidae having $55 \%$ of all galling species. Lepidoptera represented only $3.3 \%$ of galling species and $38.2 \%$ of the morphotypes could not be identified, either coming from empty galls or only found occupied by parasitoids (Hymenoptera and Diptera). Among all gall morphotypes found here, 48 are considered as new records for the host plant species (Tab. I), comparing with pertinent literature - that is, no mention of a gall on a given plant, with the structure and inducer reported here, could be found.

Galls were associated to 27 host plant families, including 40 genera and 46 nominated species (e.g. Tab. I - Figs 1-89). The most representative families were Asteraceae, with 18 gall morphotypes (20.2\%), Piperaceae with 11 (12.3\%), Fabaceae with seven (7.8\%), Myrtaceae with six $(6.7 \%)$ and Lauraceae with five $(5.6 \%)$. These families comprised $52.6 \%$ of all recorded gall morphotypes. Asteraceae also had the highest number of galled plant species $(n=7)$, while other families had four or five species. The most representative genera in gall morphotype numbers were Piper L., with 11 (12.3\%) and Mikania Willd., with $10(11.2 \%)$. Among species, those with most galls were Piper aduncum L. $(\mathrm{n}=8)$ and Mikania glomerata Spreng. $(\mathrm{n}=6)$.

Most galls were found on leaves (48.3\%) and shoots $(43.8 \%)$. Buds and fruits represented only $8.9 \%$ and $2.2 \%$, respectively. There were no galls on flowers. The most common gall shape was fusiform $(51.6 \%)$, followed by globoid $(26.9 \%)$, lenticular $(10.11 \%)$, amorphous $(3.3 \%)$, conical $(3.3 \%)$, cylindrical $(1.1 \%)$, leaf fold $(1.1 \%)$, rosette $(1.1 \%)$ and marginal roll $(1.1 \%)$. 


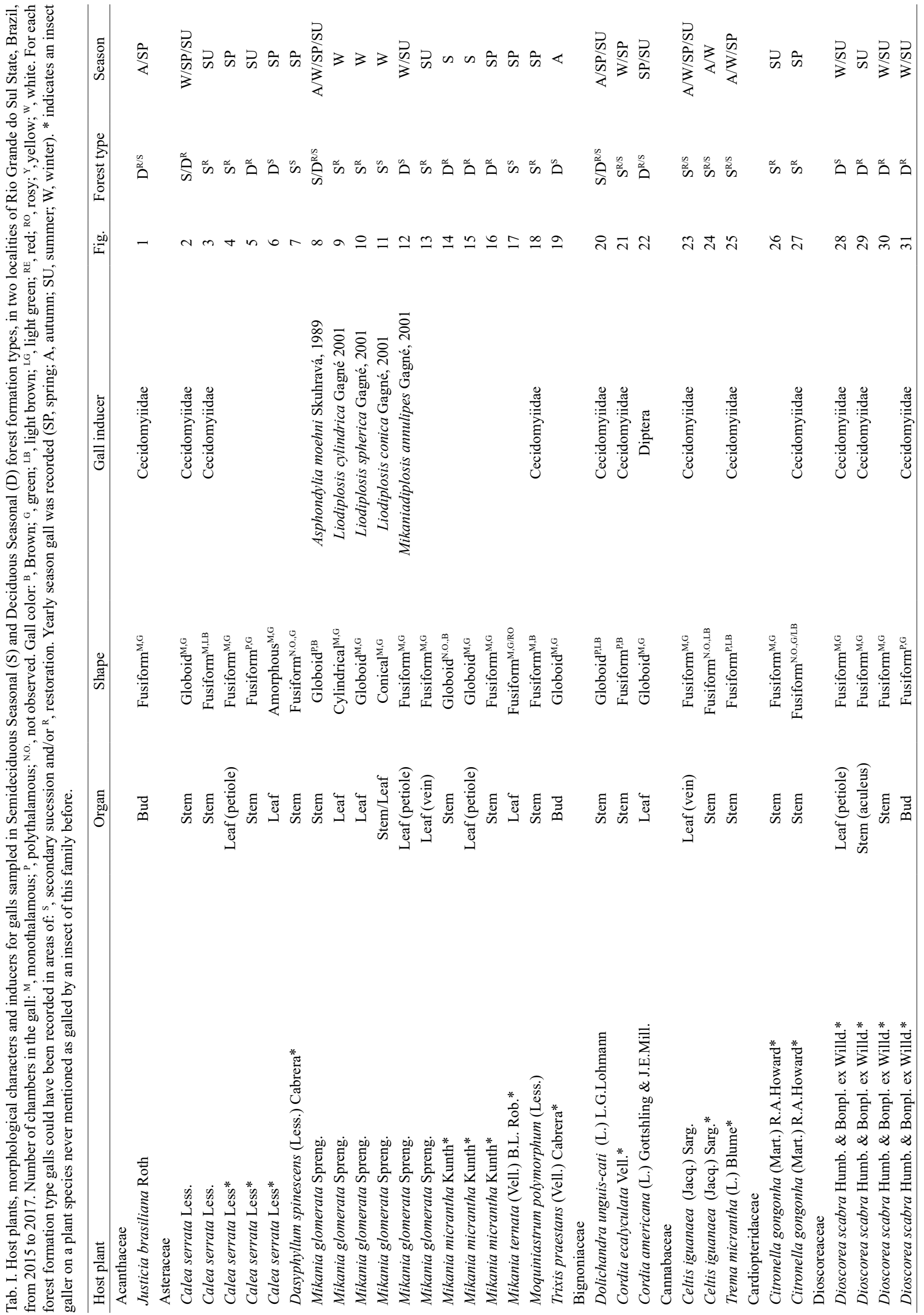




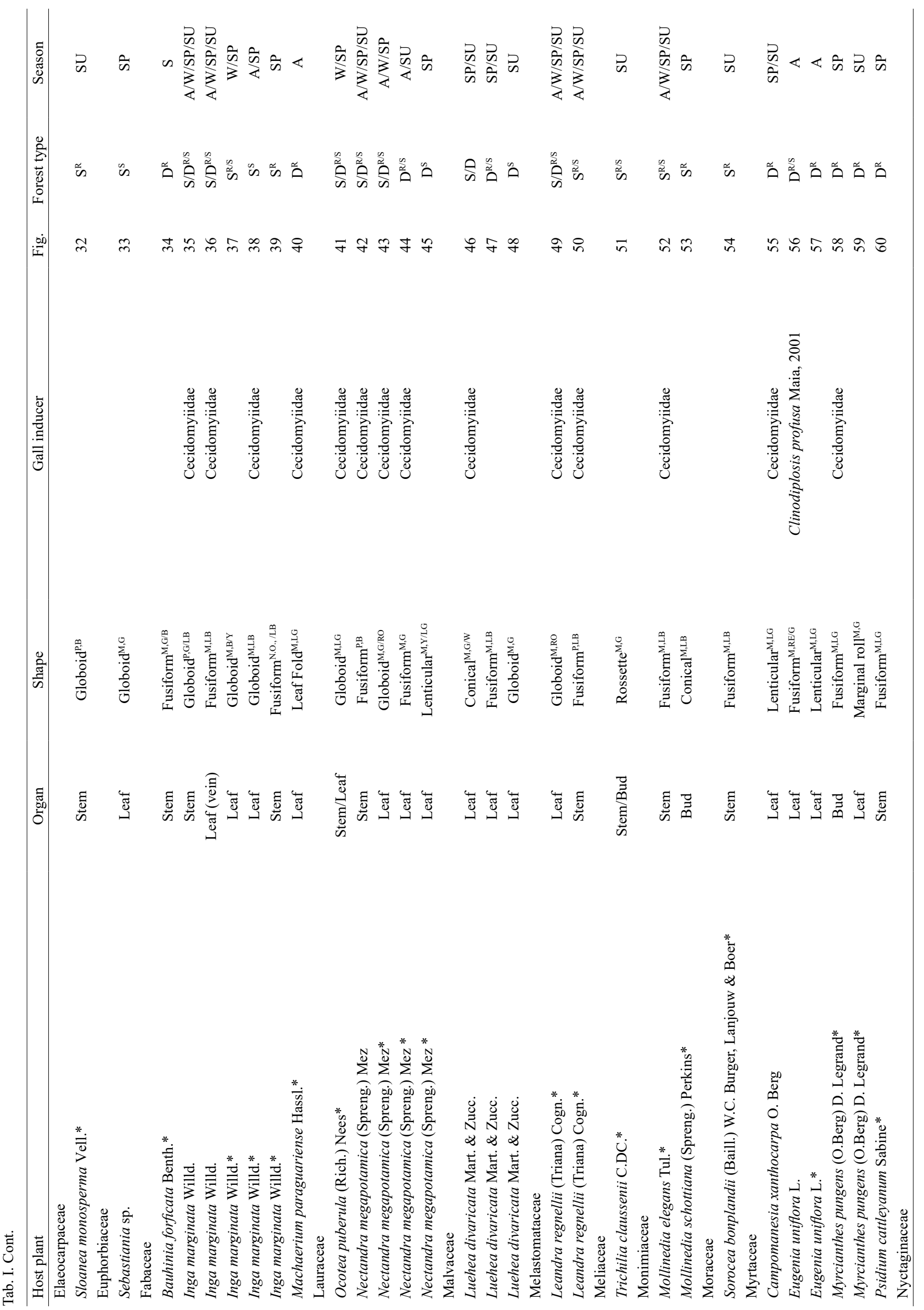




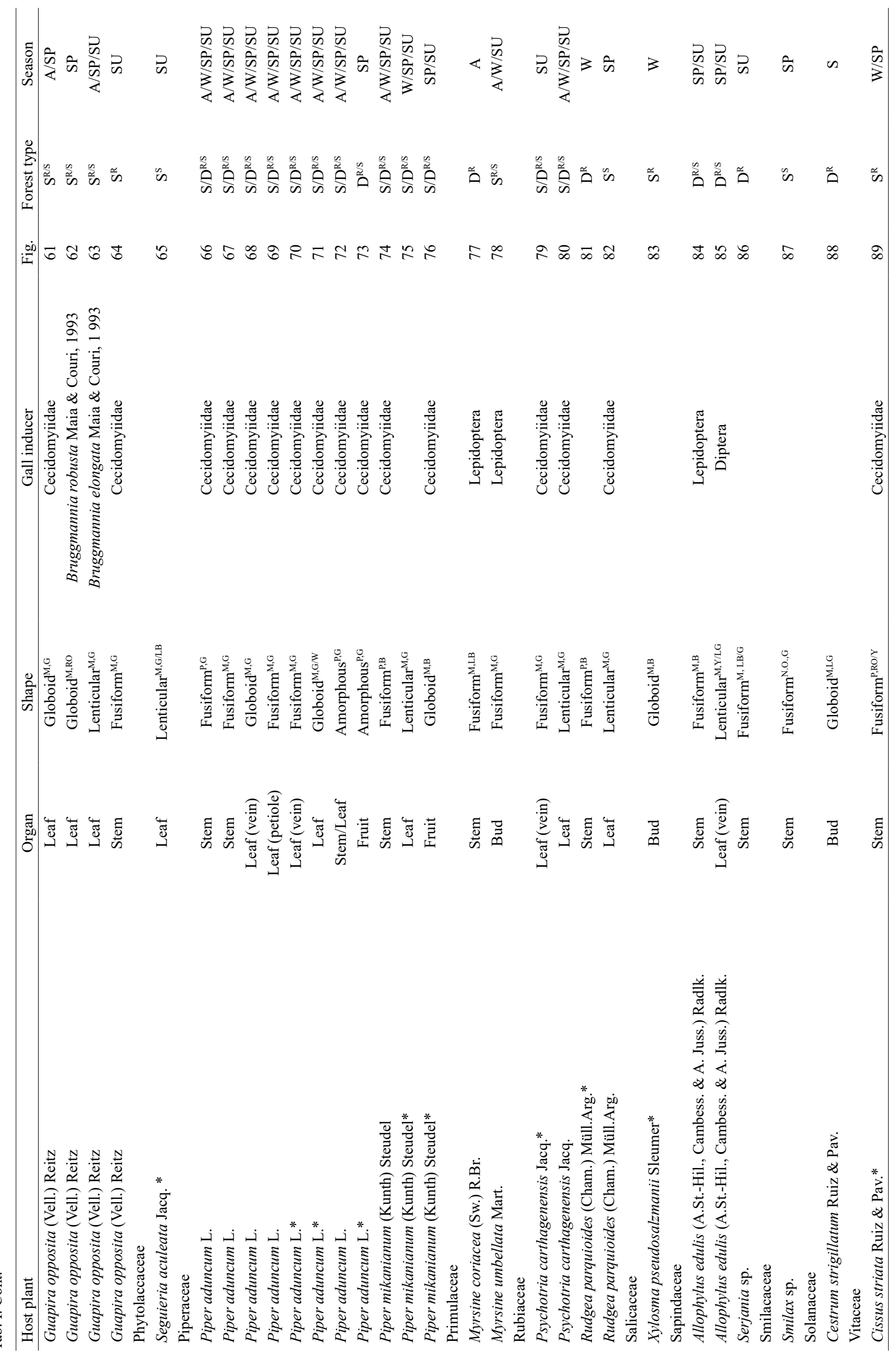



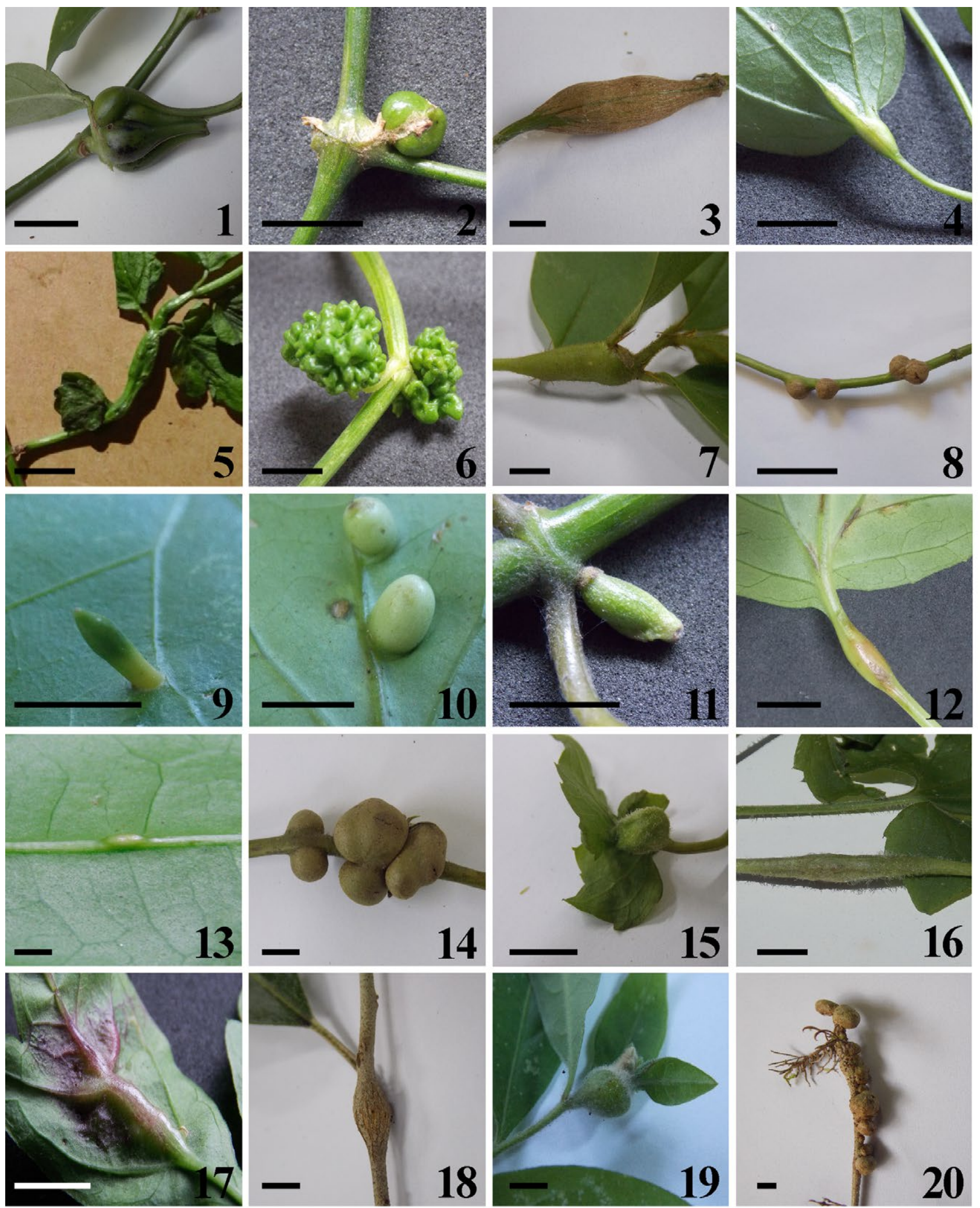

Figs 1-20. Insects galls of deciduous and semideciduous forests in Rio Grande do Sul State, Brazil: 1, Justicia brasiliana; 2-6, Calea serrata; 7, Dasyphyllum spinescens; 8-13, Mikania glomerata; 14-17, Mikania micrantha; 18, Moquiniastrum polymorphum; 19, Trixis praestans; 20, Dolichandra unguis-cati. Scale bar: $1 \mathrm{~cm}$. 

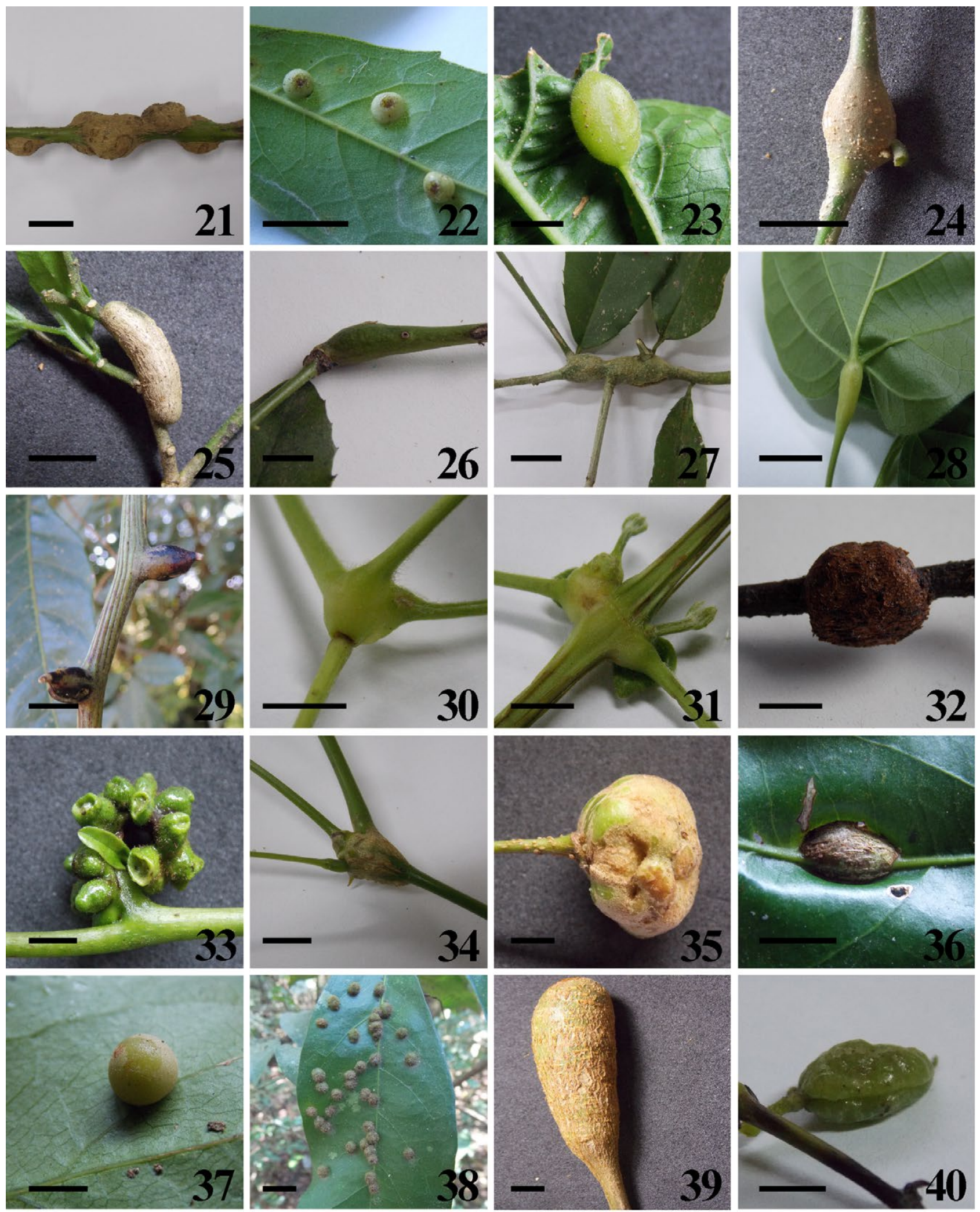

Figs 21-40. Insects galls of deciduous and semideciduous forests in Rio Grande do Sul State, Brazil: 21, Cordia ecalyculata; 22, Cordia americana; 23-24, Celtis iguanaea; 25, Trema micrantha; 26-27, Citronella gongonha: 28-31, Dioscorea scabra; 32, Sloanea monosperma; 33, Sebastiania sp.; 34, Bauhinia forficata; 35-39, Inga marginata; 40, Machaerium paraguariense. Scale bar: $1 \mathrm{~cm}$. 

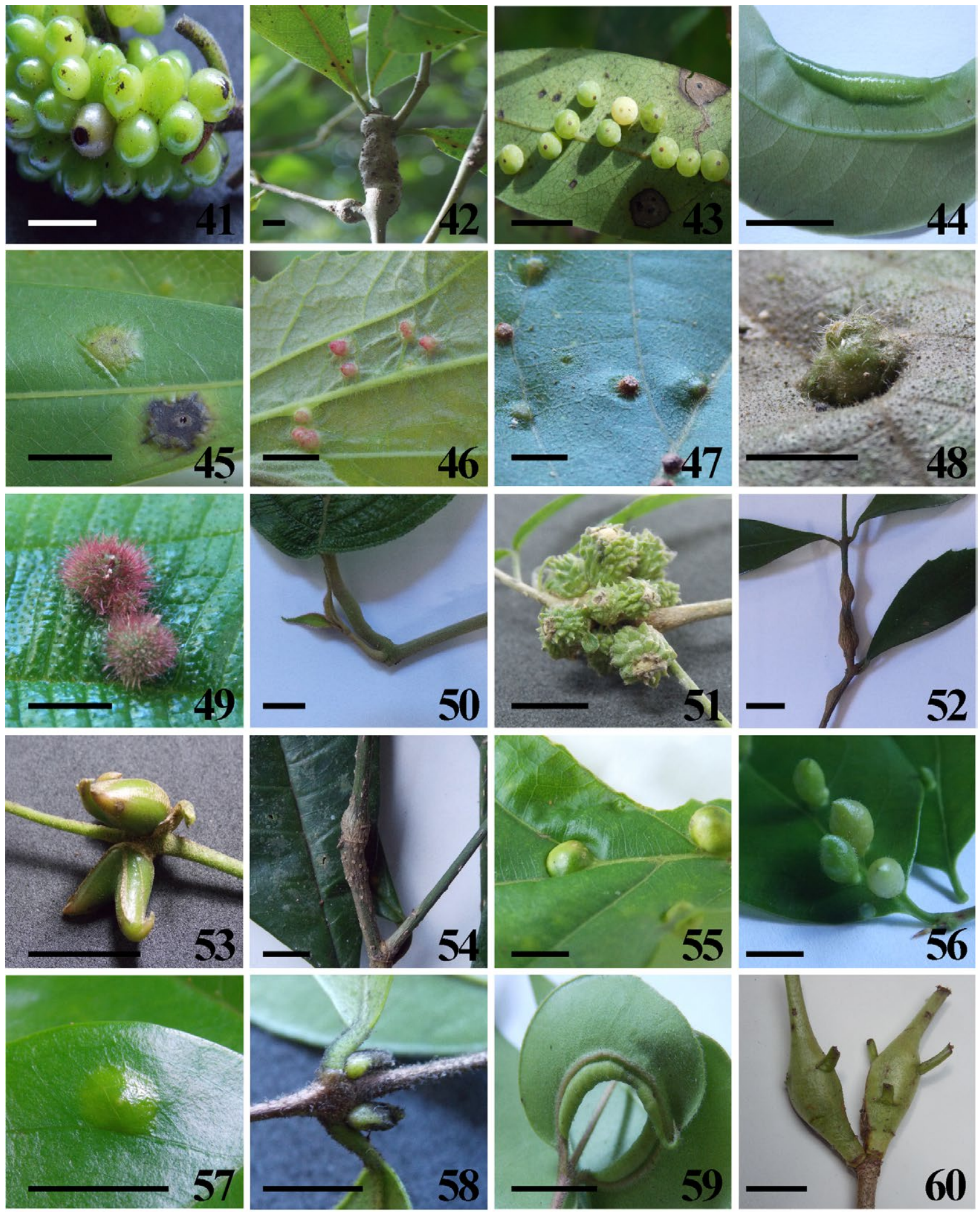

Figs 41-60. Insects galls of deciduous and semideciduous forests in Rio Grande do Sul State, Brazil: 41, Ocotea puberula; 42-45, Nectandra megapotamica; 46-48, Luehea divaricata; 49-50, Leandra regnellii; 51, Trichilia claussenii; 52, Mollinedia elegans; 53, Mollinedia schottiana; 54, Sorocea bonplandii; 55, Campomanesia xanthocarpa; 56-57, Eugenia uniflora; 58-59, Myrcianthes pungens; 60, Psidium cattleyanum. Scale bar: $1 \mathrm{~cm}$. 


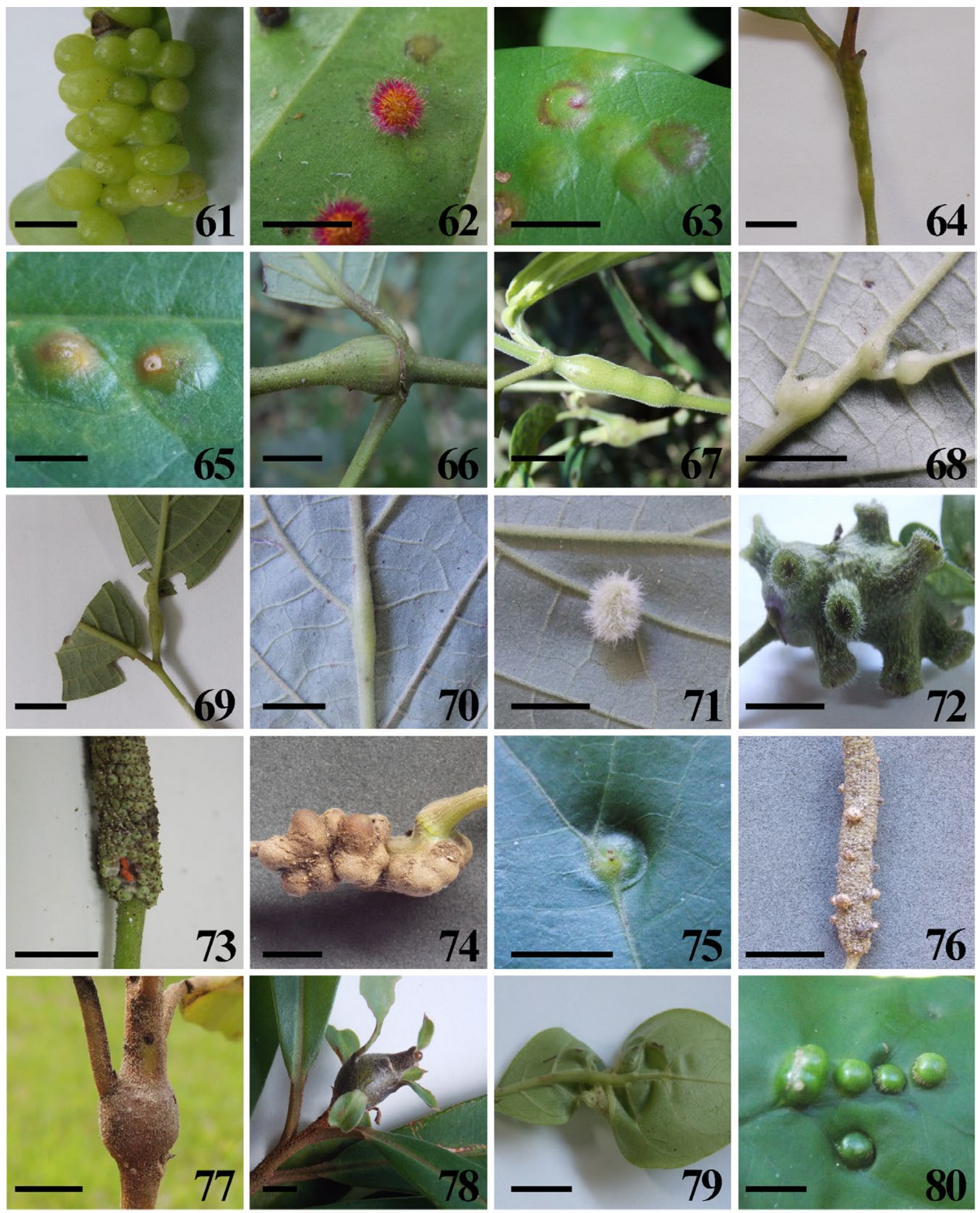

Figs 61-80. Insects galls of deciduous and semideciduous forests in Rio Grande do Sul State, Brazil: 61-64, Guapira opposita; 65, Seguieria aculeata; 66-73, Piper aduncum; 74-76, Piper mikanianum; 77-78, Myrsine coriacea; 79-80, Psychotria carthagenensis. Scale bar: $1 \mathrm{~cm}$. 

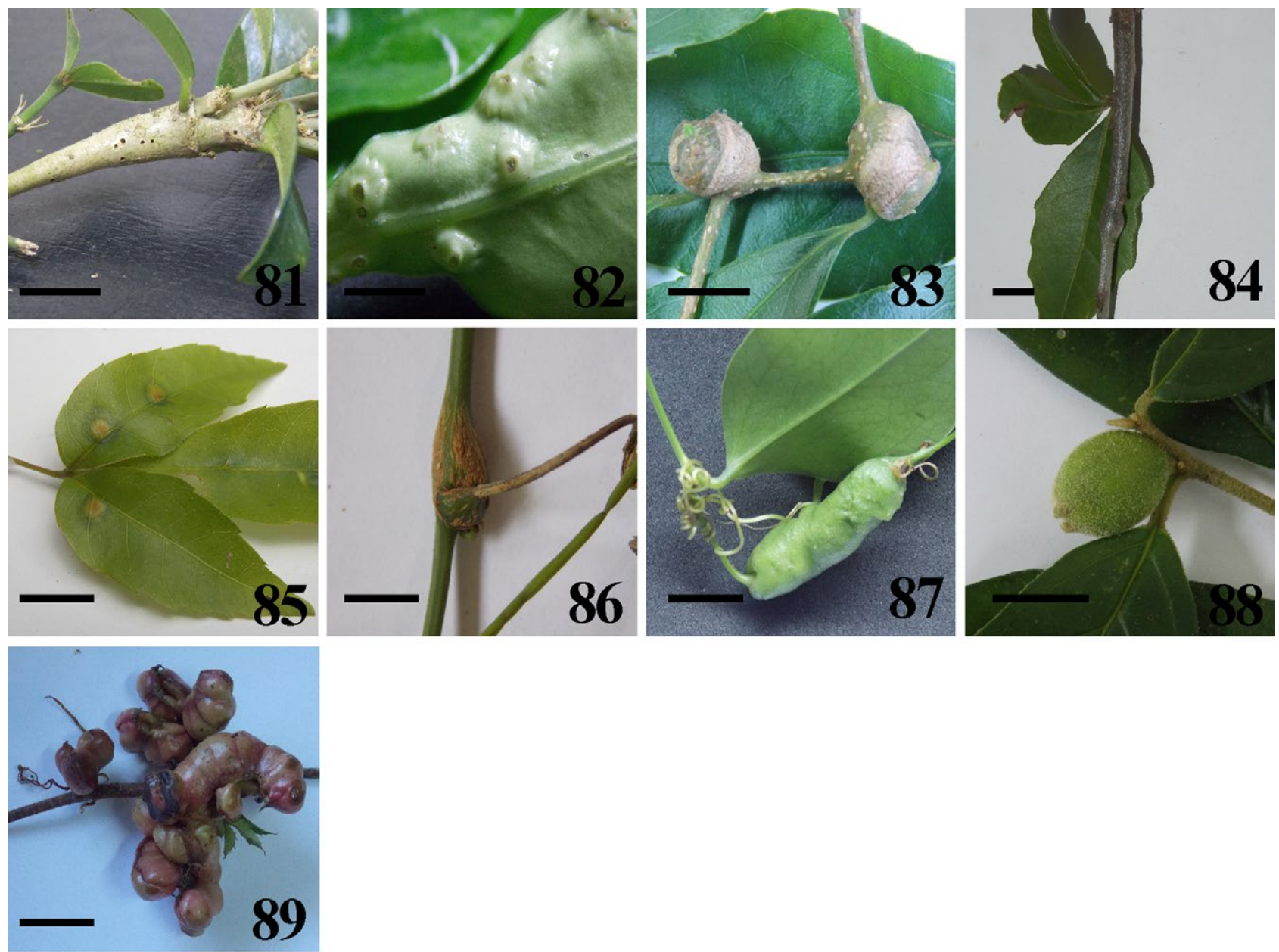

Figs 81-89. Insects galls of deciduous and semideciduous forests in Rio Grande do Sul State, Brazil: 81-82, Rudgea parquioides; 83, Xylosma pseudosalzmanii; 84-85, Allophylus edulis; 86, Serjania sp.; 87, Smilax sp.; 88, Cestrum strigillatum; 89, Cissus striata. Scale bar: $1 \mathrm{~cm}$.

\section{DISCUSSION}

The plant families with most galls in the Seasonal forests of Southern Brazil were Asteraceae, Fabaceae and Myrtaceae, all pointed out as the most common host taxa in Brazilian surveys from different regions (e.g. MaIA et al., 2014; AraúJo et al., 2015; MaIA \& CARVALHO-Fernandes, 2016). Asteraceae as the family with most galled species also agrees with what was previously found for RS State, according to MENDONÇA (2007). These members of the daisy family were also recorded as those with the higher number of morphotypes in more recent surveys in RS (e.g. Toma \& MendonçA, 2013; MendonçA et al., 2014).

Records of galls on Mikania had the highest contribution to morphotype richness in Asteraceae (10 of the 18 morphotypes in this family), with this genus already known (MENDONÇA et al., 2014) as a super-host (species or genera hosting many types of gall, VeldTMAN \& McGeOCH, 2003). Piper aduncum was the species attaining super-host status, followed by $M$. glomerata, a plant already considered as a super-host (MENDONÇA et al., 2014). Piperaceae, having this super-host species, ended up as the second most dominant family in this study, which is uncommon for gall surveys in Brazil. Cecidomyiidae as the most common inducer group was an expected result, since they comprise the richest family among galling arthropods (GAGNÉ \& JASCHHOF, 2017), being also the most common in the Neotropical region (GAGNÉ, 1994, EsPírito-SANTO \& Fernandes, 2007).

Although leaves were the main galled organ, as is usual in other work (e.g. ARAúJo et al., 2015; MAIA \& MASCARENHAS, 2017), leaves and shoots had similar proportions, as was found by Toma \& MENDONÇA (2013) for a nearby survey in araucaria forest in RS. MENDONÇA et al. (2014), considering different localities and vegetation types, pointed out that in RS there were even more galls on shoots than on leaves. This pattern of no high prevalence of galls on leaves might be related to forest deciduousness in more temperate vegetation types in Brazil, which by losing leaves during winter could represent a less lasting resource for gallers. This hypothesis, along with the geographic question of similar results on intermediate latitudes [African savanna, Veldtman \& McGeoch (2003); Neotropical rupestrian 
fields, CARNEIRO et al. (2009)], as suggested by TOMA \& MendonçA (2013), needs more specific tests and more regional comparisons, however.

Fusiform galls were more frequent, differently from other sites where the globoid form is more common (MAIA et al., 2014; NogueIRA et al., 2016), the latter being the second most common. Again, this was also found previously for the RS State by TOMA \& MENDONÇA (2013) and MENDONÇA et al. (2014). This pattern might be correlated with the abovementioned relatively higher frequency of shoot galls in these more meridional environments - shoot galls are usually fusiform (IsAIAs et al., 2013; synonymized with elliptical).

The 48 new gall morphotype records (compared to the available literature, e.g. AlmADA \& FERnANDES, 2011; Toma \& MendonÇA, 2013; MendonÇA et al., 2014; MaIA et al., 2014; ArAúJo et al., 2015; MAIA \& CARVALHO-FERnANDES, 2016; NogueIRA et al., 2016,), show how important survey work still is in this region, increasing our basic knowledge on galling insects. This expressive number of potentially new species of gallers reveals that especially in little explored different forest types (as seasonal Deciduous and Semideciduous forests), there is still much to be gained in terms of new data and new taxa.

Acknowledgments. We would like to thank CEEE-RS and Mr. Luís Brun for allowing access to the study areas; to Me. Ethiene Guerra, Prof. Mara Rejane Ritter and Dr. Milena Fermina Rosenfield for identification of host plants; and to Fundação Coordenação de Aperfeiçoamento de Pessoal de Nível Superior (CAPES) for PhD scholarships (FAL and TSPT) and Conselho Nacional de Desenvolvimento Científico e Tecnológico (CNPq) for undergraduate (APMG) and research scholarships (MSMJ) and for project funding.

\section{REFERENCES}

Almada, E. D. \& Fernandes, G. W. A. 2011. Insetos indutores de galhas em florestas de terra firme e em reflorestamentos com espécies nativas na Amazônia Oriental, Pará, Brasil. Boletim do Museu Paraense Emílio Goeldi, Ciências Naturais 6:163-196.

APG - Angiosperm Phylogeny Group IV. 2016. An update of the Angiosperm Phylogeny Group classification for the orders and families of flowering plants: APG IV. Botanical Journal of the Linnean Society 181:1-20.

Araújo, W. S.; Porfírio Júnior, E. D.; Ribeiro, B. A.; Silva, T. M.; Silva, E. C.; Guilherme, F. A. G.; Scareli-Santos, C. \& Santos, B. B. 2015. Checklist of host plants of insect galls in the state of Goiás in the Midwest Region of Brazil. Biodiversity Data Journal 3:e6835.

Carneiro, M. A. A.; Borges, R. A. X.; Araújo, A. P. A. \& Fernandes, G. W. 2009. Insetos indutores de galhas da porção sul da Cadeia do Espinhaço, Minas Gerais, Brasil. Revista Brasileira de Entomologia 53:570-592.

Carvalho, L. L. G.; Santos, R. N. S. \& Felinto, J. 2015. Ocorrência de galhas entomógenas em plantas do Parque florestal dos pioneiros, em Maringá, Paraná, Brasil. Revista UNINGÁ 23(1):21-23.

DAlbem, R. V. \& MendonçA, M. S. 2006. Diversity of galling arthropods and host plants in a subtropical forest of Porto Alegre, Southern Brazil. Neotropical Entomology 35:616-624.

Espírito-Santo, M. M.; Fagundes, M.; Nunes, Y. R. F.; Fernandes, G. W.; AzofeIfa, G. A. S. \& Quesada, M. 2006. Bases para a conservação e uso sustentável das florestas estacionais deciduais brasileiras: a necessidade de estudos multidisciplinares. Revista Unimontes Científica 8(1):13-22.

Espírito-Santo, M. M. \& Fernandes, G. W. 2007. How many species of gall-inducing insects are there on earth, and where are there? Annals of the Entomological Society of America 100:95-99.

Fernandes, G. W.; Coelho, M. S. \& Santos, J. C. 2014. Neotropical Insect Galls: Status of Knowledge and Perspectives In: Fernandes, G. W. \& SAntos, J. C. eds. Neotropical Insect Galls. London, Springer, p. 1- 14.

GAGné, R. J. 1994. The Gall Midges of the Neotropical Region. Ithaca, Cornell University Press. 352p.

Gagné, R. J. \& JaschHof, M. 2017. A Catalog of the Cecidomyiidae (Diptera) of the World. 4th. Digital. 762pp. Available at: https:// www.ars.usda.gov/ARSUserFile s/80420580/Gagne_2017_World Cat_4th_ed.pdf. Accessed on 14 november 2017.

IBGE- Instituto Brasileiro de Geografia e Estatística. 2012. Manual Técnico da Vegetação Brasileira. Rio de Janeiro, IBGE. 271p.

Isaias, R. M. S.; Carneiro, R. G. S.; Oliveira, D. C. \& Santos, J. C. 2013. Illustrated and Annotated Checklist of Brazilian Gall Morphotypes. Neotropical Entomology 42:230-239.

Maia, V. C.; Cardoso, L. J. C. \& Braga, J. M. A. 2014. Insect galls from Atlantic Forest areas of Santa Teresa, Espírito Santo, Brazil: characterization and occurrence. Boletim do Museu de Biologia Mello Leitão (Nova Série) 33:47-129.

Maia, V. C. \& CARVALho-FERnANDES, S. P. 2016. Insect galls of a protected remnant of the Atlantic Forest tableland from Rio de Janeiro State (Brazil). Revista Brasileira de Entomologia 60:40-56.

Maia, V. C. \& Mascarenhas, B. 2017. Insect Galls of the Parque Nacional do Itatiaia (Southeast Region, Brazil). Anais da Academia Brasileira de Ciências 89(1 Suppl.):505-575.

Mani, M. S. 1964. Ecology of Plant Galls. The Hague, Junk. 434p.

MEndonÇA, M. S. JR. 2007. Plant diversity and galling arthropod diversity searching for taxonomic patterns in an animal-plant interaction in the neotropics. Boletín de la Sociedad Argentina de Botánica 42(3):347357.

MendonÇA, M. S. JR. 2011. Galling arthropod diversity in the subtropical neotropics: Espinilho savannah and riparian forests compared. Revista Colombiana de Entomología 37(1):111-116.

Mendonça, M. S. JR.; Piccardi, H. M. F.; Jahnke, S. M. \& Dalbem, R. V. 2010. Galling arthropod diversity in adjacent swamp forests and restinga vegetation in Rio Grande do Sul, Brazil. Neotropical Entomology 39:513-518.

Mendonça, M. S. JR.; Toma, T. S. P. \& Silva, J. S. 2014. Galls and Galling Arthropods of Southern Brazil, In: Fernandes, G. W. \& Santos, J. C. eds. Neotropical Insect Galls. London, Springer, p. 221-256.

Moreno, J. A. 1961.Clima do Rio Grande do Sul. Porto Alegre, Secretaria da Agricultura, 42p.

Nogueira, R. M.; Costa, E. C.; Carvalho-Fernandes, S. P. \& SantosSiLVA, J. 2016. Insect galls from Serra Geral, Caetité, BA, Brazil. Biota Neotropica 16(1):e20150035.

Price, P. W.; Fernandes, G. W.; Lara, A. C. F.; Brawn, J.; Gerling, D.; Barrios, H.; Wright, M. G.; Ribeiro, S. P. \& Rothcliff, N. 1998. Global patterns in local number of insect gall-inducing species. Journal of Biogeography 25:581-591.

Santos, P. O. \& Ribeiro, J. E. L. S. 2015. Ocorrência e caracterização de galhas em fragmento de Floresta Estacional Semidecidual em Telêmaco Borba, Paraná, Brasil. Semina, Ciências Biológicas e da Saúde, 36(2):15-24.

Shorthouse, J. D.; Wool, D. \& Raman, A. 2005. Gall-inducing insects Nature's most sophisticated herbivores. Basic and Applied Ecology 6(5):407-411.

Toma, T. S. P. \& MendonçA, M. S. JR. 2013. Gall-inducing insects of an Araucaria Forest in southern Brazil. Revista Brasileira de Entomologia 57:225-233.

Veldtman, R. \& McGeoch, M. A. 2003. Gall forming insect species richness along a non-scleromorphic vegetation rainfall gradiente in South Africa: The importance of plant community composition. Austral Ecology 28:1-13. 